\title{
A Study on the Preference of Students towards Digital Reading Materials with Reference to Dindigul District
}

\section{OPEN ACCESS}

Manuscript ID:

MGT-2021-09013893

Volume: 9

Issue: 1

Month: July

Year: 2021

P-ISSN: 2321-4643

E-ISSN: 2581-9402

Received: 09.04.2021

Accepted: 25.05.2021

Published: 01.07.2021

\section{Citation:}

Durai, R., et al. "A Study on the Preference of Students towards Digital Reading Materials with Reference to Dindigul District." Shanlax International Journal of Management, vol. 9, no. 1, 2021, pp. 54-59.

DOI:

https://doi.org/10.34293/ management.v9i1.3893

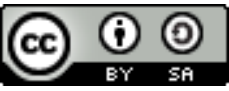

This work is licensed under a Creative Commons Attribution-ShareAlike 4.0 International License.

\author{
R. Durai \\ Director, GTN Arts \& Science College, Dindigul, Tamil Nadu, India
}

\author{
M. Sivakumar \\ Professor, Department of Entrepreneurship Studies \\ Madurai Kamaraj University, Madurai, Tamil Nadu, India
}

\author{
A. Sabarirajan \\ Professor, Department of Management Studies \\ PSNA College of Engineering and Technology, Dindigul, Tamil Nadu, India \\ https://orcid.org/0000-0001-7397-5819
}

\begin{abstract}
Innovation has become an irreplaceable marvel in contemporary time which has its effect on all social statuses and training isn't an exemption to this. The educated understudies of today have effortlessly received the electronic course books as a substitution of printed reading material attributable to its usability, cost viability, and availability. Fluctuated sees on the understudies' inclination of the predefined arrangement of reading material have laid the stage for more formal and centered exploration interests these days universally. Thusly, an exploration to separate the focal points and impediments of both the organizations and the reasons that are essential to decide on the one over the other at a provincial level is a lot of the need of great importance. The investigation planned to discover the premium and inclination that won in the brains of students of different collages in Dindigul District, Tamil Nadu regarding the embracing of electronic course readings over the printed course books as this sort of study has been completed a lot of restricted in this locale. The examination embraced a quantitative exploration plan and the poll as an examination instrument to gather the information. The outcome attests that a greater part of the understudies knows about both the configurations of reading material and are more open to utilizing electronic course books and have communicated their readiness to move from printed course readings to electronic course readings. By the by, the discoveries clarify that the understudies choose electronic course readings relying on the nature and difficulty of the subject. Keywords: Students preference, Digital contents, Learning effectiveness, Reading materials
\end{abstract}

\section{Introduction}

In the beginning the advanced innovation teaching has assumed a part in making the instructing techniques to be more successful by giving general media helps, for example, sound tracks, video clippings, live streaming and so forth. As the days progress, it has begun its intrusion into the course reading materials too as the students of today are thought of. Educators have been, utilizing more media in their instructions and fusing computerized materials, for example, scholastic games and intelligent sites into exercise plans. Be that as it may, in course of time, it has advanced to be the pioneer to transform from the printed reading material to electronic reading material which in the ongoing past has additionally evolved to be intuitive electronic course books. E-books have gotten a well known vehicle for content conveyance and are as a rule generally acknowledged as an option in contrast to customary paperbased books. 
Consequently, a careful examination to discover the inclination of the students concerning the prescribed print text book readings frames the foundation of this investigation. Dindigul area is limited by Erode, Coimbatore, Karur and Trichy locale on the North, by Sivaganga and Trichy District on the East, by Madurai region on the South and by Theni and Coimbatore Districts and Kerala State on the West. It is spread over on region of 6266.64 Sq. Km. This locale has the credit of having two Universities, viz, Mother Theresa University for Women at Kodaikanal and Gandhigram Rural Deemed University at Gandhigram. Additionally various Engineering Colleges, Arts and Science Colleges, Polytechnics, ITIs are accessible all through the region. Hence this examination is generally an endeavor to understand the need to change the method of reading course material for improving the learning experience of the students of various colleges in Dindigul District, Tamil Nadu.

\section{Literature Review}

Classroom is a room in an institution where a gathering of students are educated. The study hall is an operational place in colleges which holds students together and offers them the chance of accomplishing the purpose of education (Hill and Hill, 1990). Change or modification is essential to improvement and is exceptionally normal in each circle of life to be created. Similarly with respect to teaching in classes also needs to modify by ignoring several old techniques for coping with the present situation (Debasish \& Jantu, 2019). From the early stage, Internet is currently become a piece of social and individual existence of person. Web is a worldwide organization of PCs which are associated with everyone by wire or remotely (Ravikanth, 2019). Most of the existing literatures unanimously agree about the importance of morale in influencing work performance (Sabarirajan, 2016). Enormous and wide utility of web has gone to be a position of solace for young people, an approach to soothe their downturn, and methods for disposing of awful mindset and stress or to play and trade clever messages and jokes (Lin and Tsai, 2001).

ICT has risen as another apparatus in the field of instructing and discovering that can make conceivable many winning unimaginable realities in classroom (Drossel et al, 2017). This is the structure that causes students to get pulled in and persuaded towards learning. With the advances in data and correspondence advances, instructive exercises are presently more subject to the web and online applications. These new advancements have brought about the development of another idea, e-learning. E-learning alludes to "innovation based learning in which learning materials are conveyed electronically to far off students by means of a computer network" (Zhang et al, 2004). A few applications are utilized to help e-learning exercises, for example, course, learning and management frameworks, bookkeeping frameworks, content creation instruments and course websites (Paulsen, 2003). A Learning Management System (LMS) is one of the generally utilized applications in advanced education foundations to help course exercises in the computerized condition. The powerful execution of this apparatus is critical to improve the nature of learning, admittance to instruction and preparing, give cost-viability and decrease the expense of training.

Cybernation has become a basic wonder of the contemporary period which has its effect on each field of development (Mohanad and Janaki, 2020). Advanced innovation is utilized for correspondence, socialization, amusement and learning data. It has its huge task to carry out in the territory of instruction also (Weisburg, 2011). (Karabatzaki, 2018) affirmed that utilization of innovation has advanced students commitment significantly. Since the time the start of antiquated development, training has been changing its structure attributable to the cultural movements. Subsequently, in the present period, instruction will undoubtedly inject innovation to make the encouraging intriguing and the learning experience only useful as well as captivating and sensational by utilizing changed computerized devices implied for training and the e contents have become an indivisible aspect of the instructive framework (Dayakar, 2018). People are currently used to delivering, composing, putting away and recovering reports electronically on a wide scope of electronic gadgets (Makwanya and Oni, 2019). In the assessment of Simon and Simon and Garcia (2016), the technically knowledgeable mindset of the contemporary students has invited the infringement of creative innovations into the educating and learning measure. Regardless of the 
ages, the primary motivation behind training has consistently been to assist students with turning out to be independent learners, ready to ask, comprehend, and break down thoughts and utilize their insight to take care of issues (Dobler, 2015).

In the view of Lokar (2015), electronic course materials could be sensibly less expensive than printed course materials and as per Chulkov and Van Alstine (2013), the inclination for the reading material depends on "cost, simplicity of procurement, capacity to keep the book, and match to their learning style." Nevertheless, Lee et al (2013) noticed that the practice of going advanced digital reading incures cost additionally. The expense contains acquisition of keen gadgets, establishment of programming, upkeep of equipment, network framework, extra frill, web utilization, operational costs, redesign and substitution costs, refreshing of against infection, and expert preparing. In any case, accessibility of a wide scope of electronic gadgets at sensible costs make it conceivable and moderate for individuals to possess the keen gadgets as per Wiese and Du Plessis (2014). Asunka (2013) believed that during the 1970s the electronic reading material are simply digitalized print books with no additional specialized highlights or intuitive instruments which was additionally affirmed by Choppin et al (2014). The data and news is currently accessible to numerous people effortlessly (Venkateswaran et al, 2019). Consequently, these were not assuming a significant part in improving the learning experience of learners or helping the instructors in upgrading the adequacy of the enhanced instructional methods. Rather than encouraging the instructing experience to be more agreeable, electronic course materials gave a trouble to educators inferable from the absence of preparing, contrariness among assets and gadgets, helpless receptivity, buffering because of low speed internet connection, eye strain, posture issues, and user obstruction - hampering the smooth running of classes with electronic reading materials.

In 2010, this variant was additionally evolved with a couple of more included highlights the brilliant gadgets, for example, "essential note taking, highlighting options, and search capacities," as affirmed by Weisberg (2011). However, Mizrachi et al. (2018) discovered that the learners wanted to print out for highlighting the text instead of utilizing
E-contents. Muir and Hawes (2013) found that the learners need updated interface to improve the learning experience and as per Baker and Stone (2015), the learners access electronic course materials to see, "content on a web page, a PDF content, or on an electronic reading gadget." Almost all the electronic course material arrive in a PDF design as it is viewed as more easy to use and almost all PCs and other advanced processing gadgets, for example, PDAs and tablets have programming that will deliver PDF documents without reducing quality of the original content (Feldstein et al., 2012). Further, Beetham and Sharepe (2013) pinpointed that, "It is questionable that there is no requirement for a hypothesis of innovation improved learning. Innovation can assume a significant function in the accomplishment of learning results; however it appears to be pointless to clarify this improvement with an exceptional record of learning. Or maybe, the test is to depict how the innovation permits basic cycle normal to all figuring out how to work viably." Hence, it gets inescapable to discover from the different sources the adequacy of utilization of electronic reading material and whether the successful utilize is variable to the sort of scholastic order picked. The findings of the examination would lay an extension for the total appropriation of electronic course materials by the colleges or keeping up the current pattern of blend of printed and electronic course books.

\section{Research Methodology}

In the study, quantitative assessments were used to test the responses collected from students. Relevant to the objective of the study, the structured questionnaire was prepared based on the earlier researches referred and modified according to the requirement of the current study. Data collected from respondents of various colleges in Dindigul district through online mode. The questionnaire utilized to enumerate the demographic data such as, age, sex, level of study and level of awareness in terms of print books and e-books. Out of 300 responses received 240 responses were selected based on completeness. Hence the sample size turned to be 240 in which Male students 130, Female Students 110, out of which the significant $64.6 \%$ are in the age group of Below 20 and $29.2 \%$ are in the age group $21-25$ years. Only $2.1 \%$ are from above 30 years. 
Table 1: Program wise Distribution of Respondents

\begin{tabular}{|c|l|c|c|c|c|}
\hline \multicolumn{2}{|c|}{ Program } & Frequency & Percent & Valid Percent & Cumulative Percent \\
\hline \multirow{5}{*}{} & Arts & 32 & 13.3 & 13.3 & 13.3 \\
\cline { 2 - 6 } & Engineering & 114 & 47.5 & 47.5 & 60.8 \\
\cline { 2 - 6 } Valid & Science & 73 & 30.4 & 30.4 & 91.2 \\
\cline { 2 - 6 } & Others & 21 & 8.8 & 8.8 & 100 \\
\cline { 2 - 6 } & Total & 240 & 100 & 100 & \\
\hline
\end{tabular}

\section{Student's Preference towards Printed Text Books}

In the study $33.5 \%$ of the respondents reported that they had sometimes used the printed textbooks, $28.3 \%$ mentioned that they had been using printed textbooks frequently, $22.7 \%$ mentioned that they used the printed textbooks only during the regular classes and $15.5 \%$ mentioned that had never used the printed textbooks at all. The responses make it very clear that the printed textbooks are losing its significance amidst the college students as the college students of these days have a tendency to resort to the notes taken in the classes, abstracts from the current research studies and various on-line resources for the information acquisition. The numbers of college students utilizing printed textbooks frequently and only during regular classes are gradually going down. When explored further, the respondents listed the following as the inconveniences of printed textbooks:

Table 2: Respondents Perceptions on Preference and Inconvenience of Printed Textbooks

\begin{tabular}{|l|c|c|c|c|}
\hline \multicolumn{1}{|c|}{ Preference } & $\begin{array}{c}\text { 1st } \\
\text { Choice }\end{array}$ & $\begin{array}{c}\text { 2nd } \\
\text { Choice }\end{array}$ & $\begin{array}{c}\text { 3rd } \\
\text { Choice }\end{array}$ & $\begin{array}{c}\text { 4th } \\
\text { Choice }\end{array}$ \\
\hline $\begin{array}{l}\text { Lending and } \\
\text { borrowing } \\
\text { possible }\end{array}$ & 26.4 & 33.5 & 30.1 & 10 \\
\hline Touch and feel & 12.2 & 9.5 & 17.3 & 61 \\
\hline $\begin{array}{l}\text { Highlighting } \\
\text { and notes } \\
\text { marking }\end{array}$ & 21.3 & 29.5 & 27.9 & 21.3 \\
\hline No eye strain & 40.1 & 27.5 & 24.7 & 7.7 \\
\hline $\begin{array}{l}\text { Inconvenience } \\
\text { Choice }\end{array}$ & Choice & Choice & Choice \\
\hline $\begin{array}{l}\text { Print book } \\
\text { weight }\end{array}$ & 39.5 & 24.3 & 22.5 & 13.7 \\
\hline $\begin{array}{l}\text { Occupies more } \\
\text { space }\end{array}$ & 25.6 & 32.1 & 34.5 & 7.8 \\
\hline
\end{tabular}

\begin{tabular}{|l|c|c|c|c|}
\hline More cost & 29.5 & 35.4 & 26.2 & 8.9 \\
\hline $\begin{array}{l}\text { Requires } \\
\text { lighting to read }\end{array}$ & 5.4 & 8.2 & 16.8 & 69.6 \\
\hline
\end{tabular}

The responses make it very clear that majority of the students preferred printed textbook for not making eye strain while reading and easiness in Lending and borrowing of books. Similarly most of them face inconvenience in carrying books because of its weight and the cost of text books also higher.

Table 3: Respondents Perceptions on Preference towards E-books

\begin{tabular}{|l|c|c|c|c|}
\hline \multicolumn{1}{|c|}{ Preference } & $\begin{array}{c}\text { 1st } \\
\text { Choice }\end{array}$ & $\begin{array}{c}\text { 2nd } \\
\text { Choice }\end{array}$ & $\begin{array}{c}\text { 3rd } \\
\text { Choice }\end{array}$ & $\begin{array}{c}\text { 4th } \\
\text { Choice }\end{array}$ \\
\hline $\begin{array}{l}\text { Easy and Quick } \\
\text { Access }\end{array}$ & 40.7 & 30.5 & 26.1 & 2.7 \\
\hline Reduced cost & 31.4 & 29.5 & 27.1 & 12 \\
\hline $\begin{array}{l}\text { Less storage } \\
\text { space }\end{array}$ & 22.7 & 28.5 & 28.5 & 20.3 \\
\hline $\begin{array}{l}\text { Ease of } \\
\text { Archiving }\end{array}$ & 5.2 & 11.5 & 18.3 & 65 \\
\hline $\begin{array}{l}\text { Inconvenience } \\
\text { Choice }\end{array}$ & Choice & Choice & Choice \\
\hline $\begin{array}{l}\text { Difficulty in } \\
\text { prolonged } \\
\text { reading }\end{array}$ & 34.5 & 24.3 & 27.5 & 13.7 \\
\hline $\begin{array}{l}\text { Need additional } \\
\text { devices to read }\end{array}$ & 25.6 & 32.1 & 34.5 & 7.8 \\
\hline $\begin{array}{l}\text { Inconvenient } \\
\text { position }\end{array}$ & 29.5 & 35.4 & 26.2 & 8.9 \\
\hline $\begin{array}{l}\text { Adaptability } \\
\text { problems }\end{array}$ & 10.4 & 8.2 & 11.8 & 69.6 \\
\hline
\end{tabular}

In the study $42.8 \%$ of the respondents mentioned that they had sometimes used the electronic textbooks, $31.2 \%$ mentioned that they had been using electronic textbooks regularly, $22.7 \%$ mentioned that they used the electronic textbooks only during the classes and $3.3 \%$ mentioned that had never used the electronic 
textbooks at all. The responses make it very clear that the electronic textbooks are gaining its momentum amidst the students which is in alignment with the findings of Hendricks and Leonard \& Snyman because the students of today find it easier to access the online materials owing to the smart devices and high-speed internet that are available to them at a reasonable price.

\section{Discussions}

The respondents suggested that electronic textbooks are the best for academic disciplines like social sciences, management studies and languages in the order of preference. This may be because of highly theoretical nature of the courses pertaining to these educational disciplines. This requires an attention that the developers of digital textbooks and other online materials have to pay more attention in designing the digital textbooks pertaining to science area in order to facilitate students. In addition, the participants were aware of the necessity of the smart devices and varied formats of electronic textbooks. Further, they possessed the advanced knowledge of the latest interactive tools available on electronic textbooks and the thorough awareness of the need for high speed internet for the knowledge transmission through electronic textbooks. Since the students had the experience of handling both the formats of textbooks, the findings of this study become more authentic. In addition, the respondents possessed the knowledge to compare the effective knowledge transfer of varied subjects too.

\section{Conclusion}

This study identified the reasons behind the students' preference of printed or electronic versions of textbooks only taking into consideration the students of various colleges in Dindigul district through online mode. Hence, it lays the scope to extend the study for the entire student population of the whole country or the region for a more concrete result. Longitudinal research should be initiated in future to decide on the complete adoption of electronic textbooks in the higher educational institutes. Comparing the trend with other countries can also facilitate more interpretations in this regard. Despite the repeated researches in various parts of the globe, the question of making printed or traditional textbooks completely dispensable is still unanswered. However, the changing trend of modernization and evolution of technology on a dayto-day basis may lead to complete switch over from printed textbooks to electronic textbooks.

\section{References}

Asunka, Stephen. "The Viability of e-textbooks in Developing Countries: Ghanaian University Students' Perceptions." Open Learning, vol. 28, no. 1, 2013, pp. 36-50.

Baker-Eveleth, Lori, and Robert W. Stone. "Usability, Expectation, Confirmation, and Continuance Intentions to Use Electronic Textbooks." Behaviour \& Information Technology, vol. 34, no. 10, 2015, pp. 992-1004.

Beetham, Helen, and Rhona Sharpe. Rethinking Pedagogy for a Digital Age: Designing for 21st Century Learning. Routledge, 2013.

Choppin, Jeffrey, et al. "A Typology for Analyzing Digital Curricula in Mathematics Education." International Journal of Education in Mathematics, Science and Technology, vol. 2, no. 1, 2014, pp. 11-25.

Chulkov, Dmitriy V., and Jason VanAlstine. "College Student Choice among Electronic and Printed Textbook Options." Journal of Education for Business, vol. 88, no. 4, 2013, pp. 216-222.

Dayakar, G. "Use of e-resources in Higher Education: Advantages and Concerns." Journal of Applied and Advanced Research, vol. 3, 2018. Debbarma, Debasish, and Jantu Das. "Attitude of Teachers towards Using ICT in Schools: A Study in Tripura." Research and Reflections on Education, vol. 17, no. 4, 2019.

Dobler, Elizabeth. "E-textbooks." Journal of Adolescent \& Adult Literacy, vol. 58, no. 6, 2015, pp. 482-491.

Drossel, Kerstin, et al. "Predictors of Teachers' Use of ICT in School - The Relevance of School Characteristics, Teachers' Attitudes and Teacher Collaboration." Education and Information Technologies, vol. 22, 2017.

Feldstein, Andrew, et al. "Open Textbooks and Increased Student Access and Outcomes." European Journal of Open, Distance and E-Learning, 2012. 
Hendricks, D. "Why Digital Publishing is the Future of Education." Inc.com, 2017.

Hill, Susan, and Timothy Hill. The Collaborative Classroom: A Guide to Co-operative Learning. Penguin Random House, 1990.

Karabatzaki, Zoe, et al. "Mobile Application Tools for Students in Secondary Education: An Evaluation Study." International Journal of Interactive Mobile Technologies, vol. 12, no. 2, 2018, pp. 142-161.

Lee, HeeJeong Jasmine, et al. "Can an Electronic Textbooks be Part of K-12 Education? Challenges, Technological Solutions and Open Issues." Turkish Online Journal of Educational Technology, vol. 12, no. 1, 2013.

Tsai, Chin-Chung, and Sunny S.Lin. "Analysis of Attitude toward Computer Network and Internet Addiction of Taiwanese Adolescents." CyberPsychology \& Behavior, vol. 4, no. 3, 2001, pp. 373-376.

Leonard, Anna, and Maritha Snyman. "E-books: Yes or No? A Case Study of Undergraduate Students at the University of Namibia." Collection and Curation, vol. 38, no. 3, 2019.

Lokar, Matija. "The Future of e-textbooks." International Journal for Technology in Mathematics Education, vol. 22, no. 3, 2015.

Makwanya, Comfort, and Olabanji Oni. "E-books Preference Compared to Print Books based on Student Perceptions: A Case on University of Fort Hare Students." International Journal of Interactive Mobile Technologies, vol. 13, no. 12,2019 , pp. 236-245.

Mizrachi, Diane, et al. "Academic Reading Format Preferences and Behaviors among University Students Worldwide: A Comparative Survey Analysis." PloS One, vol. 13, 2018.

Alfiras, Mohanad, and Janaki Bojiah. "Printed Textbooks Versus Electronic Textbooks: A Study on the Preference of Students of
Gulf University in Kingdom of Bahrain." International Journal of Emerging Technologies in Learning, vol. 15, 2020.

Muir, Laura, and Graeme Hawes. "The Case for e-book Literacy: Undergraduate Students' Experience with e-Books for Course Work." The Journal of Academic Librarianship, vol. 39, no. 3, 2013, pp. 260-274.

Paulsen, Morten Flate. "Experiences with Learning Management System in 113 European Institutions." Educational Technology \& Society, vol. 6, no. 4, 2003, pp. 134-148.

Kant, Ravi. "Exploring Internet Addiction on University Students: A Study of Central University of South Bihar, Gaya." Research and Reflections on Education, vol. 17, 2019.

Sabarirajan, A. "A Study on Employee Morale and Job Satisfaction among the Employees of Spinning Mills at Dindigul District." Shanlax International Journal of Management, vol. 4, no. 2, 2016, pp. 134-139.

Simon, Josep, and Antonio Garcia-Belmar. "Education and Textbooks." Technology and Culture, vol. 57, 2016, pp. 940-950.

Venkateswaran, P.S., et al. "The Theory of the Postmodernism in Consumerism, Mass Culture and Globalization." The Journal of Research on the Lepidoptera, 2019.

Weisberg, Mitchell. "Student Attitudes and Behaviors towards Digital Textbooks." Publishing Research Quarterly, vol. 27, 2011.

Wiese, Melanie, and Giselle du Plessis. "The Battle of the e-textbook: Libraries' Role in Facilitating Student Acceptance and Use of e-Textbooks." South African Journal of Libraries \& Information Science, vol. 80, no. 2, 2014, pp. 17-26.

Zhang, Dongsong, et al. "Can E-Learning replace Classroom Learning?" Communication of the $A C M$, vol. 47 , no. 5,2004 , pp. 75-79.

\section{Author Details}

R. Durai, Director, GTN Arts \& Science College, Dindigul, Tamil Nadu, India

Dr. M. Sivakumar, Professor, Dept. of Entrepreneurship studies, Madurai Kamaraj University, Madurai, India

Dr. A. Sabarirajan, Professor, Department of Management Studies, PSNA College of Engineering and Technology, Dindigul, Tamil Nadu, India, Email ID: a.sabarirajan@gmail.com 